\title{
Proales tillyensis sp.n. (Monogononta: Proalidae), a new rotifer species from North-West Germany, with reconstruction of its somatic musculature
}

\author{
E.F. Wilts, W.H. Ahlrichs
}

Systematics and Evolutionary Biology, Department of Biology and Environmental Sciences, Carl von Ossietzky University Oldenburg, 26111 Oldenburg, Germany.

e-mail:eike.f.wilts@mail.uni-oldenburg.de

ABSTRACT: We here describe a new proalid rotifer species Proales tillyensis sp.n. from Oldenburg, North-West Germany. The species was initially found in the ph-neutral water of Lake Tilly in August 2006. Its description is based on light and electron microscopy, providing different views of both the whole specimen and its trophi. Additionally, the body musculature of the species was visualized by confocal laser scanning microscopy using fluorescent-labelled phalloidin and compared with the musculature of other Proales species. Proales tillyensis sp.n. resembles P. fallaciosa Wulfert, 1937 and P. decipiens (Ehrenberg, 1832) but differs in its ecology. Furthermore it can be diagnosed from the former species by the absence of a knob-like projection between the toes, the small body size, the number of uncus teeth and the organization of body musculature. From the latter species it can be diagnosed by the number of uncus teeth, the small body size and the lack of a constriction between stomach and intestine.

KEY WORDS: Proales tillyensis n.sp., Rotifera, Proalidae, CLSM, somatic musculature.

\section{Proales tillyensis sp.n. (Monogononta: Proalidae): новый вид коловраток из северо-западной Германии с реконструкцией соматической мускулатуры}

\author{
Е.Ф. Вилц, В.Г. Алрихс
}

Systematics and Evolutionary Biology, Department of Biology and Environmental Sciences, Carl von Ossietzky University Oldenburg, 26111 Oldenburg, Germany.

e-mail:eike.f.wilts@mail.uni-oldenburg.de

РЕЗЮМЕ: Описан новый вид проалидной коловратки Proales tillyensis sp.n. из Ольденбурга (северо-западная Германия). Вид был обнаружен в рН нейтральной воде в озере Тилли в августе 2006 г. Особи были изучены методами световой и электронной микроскопии. Были получены фотографии целых животных и их ротовых частей. Дополнительно было проведено изучение соматической мускулатуры нового вида с помощью флюорисцентной фаллоидиновой метки и проведено сравнение с организацией мускулатуры у других коловраток рода Proales. Proales tillyensis sp.n. сходен с P. fallaciosa Wulfert, 1937 и P. decipiens (Ehrenberg, 1832), но их экология различна. Кроме того, от P. fallaciosa новый вид отличается отсутствием бородавкообразного выроста между пальцами, мелкими размерами тела, иным 
числом зубов ункуса и иной организация соматической мускулатуры. От $P$. decipiens новый вид отличается числом зубов ункуса, мелкими размерами тела и отсутствием перетяжки между желудком и кишкой.

КЛЮЧЕВЫЕ СЛОВА: Proales tillyensis sp.n, коловратки, Proalidae, конфокальная лазерная сканирующая микроскопия, соматическая мускулатура.

\section{Introduction}

The monogonont rotifer taxon Proalidae, Proales Gosse, 1886 comprises a genus with currently 44 species (Segers, 2007). From a systematic point of view Proales is problematic and in need of a revision because it represents an assemblage of diverse species from which several have been moved in and out in the past (Segers, 1995; Wilts et al., 2009a; De Smet, in press.). Koste (1978) already subdivided the species of Proales into two main groups: Group A (group Proales sensu stricto) comprises freshwater species that resemble the type species $P$. decipiens and are characterized by a tubular habitus with a trunk comprising multiple pseudosegments, a hardly offset head with a rostrum and a short foot, a cerebral eye and an elongated buccal field. The other group comprises almost unexceptionally marine species resembling Proales reinhardti (group B, misleadingly designated as group Proales sensu stricto by Wilts et al., 2009a). The representatives of this group are characterized by a bulbous trunk with an offset head and a long foot, apical eyes and two epidermal projections restricting the apical corona caudally.

We found a new species in a lake near Oldenburg, North-West Germany occuring in floating gras material during warm periods of the summer months. The new species fits group A, resembling $P$. fallaciosa and $P$. decipiens. In the following we describe the species carefully on the basis of light and scanning electron microscopic (SEM) findings, and give standardised views of the specimen and its trophi. Furthermore, we analyze the somatic musculature of the species using confocal laser scanning miscoscopy (CLSM) in order to provide a broader overview of the variation of the muscular pattern across Proales.

\section{Material and methods}

Samples were collected during August 2006, 2008 and 2009 from Lake Tilly in Oldenburg, north-western Germany $\left(53^{\circ} 04^{\prime} 35.0^{\prime \prime} \mathrm{N}, 7^{\circ} 12^{\prime}\right.$ $\left.00.07^{\prime \prime} \mathrm{E}\right)$ with a plankton sieve of $64 \mu \mathrm{m}$ mesh size. Single rotifer specimens were studied by both differential interference contrast light microscopy (Leica DMLB) and scanning electron microscopy (Zeiss DSM 940). Light microscopic images were taken with a digital camera (Olympus ColorView). Isolated rotifer specimens were narcotized with an aqueous solution of $0.25 \%$ bupivacaine (Bucain $\AA$ ) and fixed with $4 \% \mathrm{OsO}_{4}$ in $0.1 \mathrm{M}$ sodium cacodylate buffer and picric acid formaldehyde at $240 \mathrm{mOsm}$ (after Melone, 1998). Specimens were dehydrated in a graded ethanol series followed by criticalpoint drying. Dried specimens were mounted on stubs. For trophi preparations, individual specimens were dissolved under a stereo microscope (Leica MZ12 ${ }_{5}$ ) following the procedure given by Kleinow et al. (1990) leaving only the cuticularized trophi elements. Trophi were rinsed and dried on a coverslip and mounted on stubs. Specimens and trophi were coated with gold and studied by scanning electron microscopy. For CLSM, specimens were anaesthetized with bupivacaine, fixed for $1 \mathrm{~h}$ in phosphate-buffered $4 \%$ paraformaldehyde, rinsed in $0.1 \mathrm{M}$ phosphate-buffered saline (PBS), and then made permeable for staining by exposure to $0.1 \%$ Triton X-100 buffered in $0.1 \mathrm{M}$ PBS for $1 \mathrm{~h}$. For staining, $2 \mathrm{ml}$ of $38 \mathrm{mM}$ methanolic TRITClabelled phalloidin solution were added to 100 $\mathrm{ml}$ of Triton X-100 buffered in 0.1 M PBS. Specimens were stained for $3 \mathrm{~h}$ and mounted in Citifluor ${ }^{\circledR}$ on a coverslip; a total of five specimens were analyzed. The images were obtained under a wavelength of $488 \mathrm{~nm}$ using a Leica 
TCS SP 5 confocal laser scanning microscope. We used Leica LAS AF 1.7.0 for the analysis of the image stacks. All line drawings were prepared with Adobe Photoshop ${ }^{\circledR}$ CS2 .

\section{Order Ploima Hudson \& Gosse, 1886}

Family Proalidae Bartos, 1959

\section{Genus Proales Gosse, 1886}

\section{Proales tillyensis sp.n.}

MATERIAL. Holotype. A parthenogenetic female in a permanent, glycerin glass slide mount deposited at Museum fur Naturkunde, Germany, Berlin (ZMB) Generalkatalog freilebende Wurmer ZMB Vermes 11372.

Paratypes. Three parthenogenetic females in permanent, glycerin glass slide mounts (ZMB Vermes 11373-1, -2 and -3$)$, ten parthenogenetic females mounted on a SEM stub (ZMB Vermes 11373-4, -5, -6, -7, -8, -9, 10, -11, -12 and -13$)$ and a trophi preparation with three trophi mounted on a SEM stub (ZMB Vermes 11373-14, -15 and -16).

TYPE LOCALITY. Lake Tilly in Oldenburg, Lower Saxony, Germany. August 2006, 2008, $2009\left(53^{\circ} 04^{\prime} 35.02^{\prime \prime} \mathrm{N}, 7^{\circ} 12^{\prime} 00.07^{\prime \prime} \mathrm{E}\right)$.

ETYMOLOGY. The species name tillyensis is derived from the type locality Lake Tilly in Oldenburg.

DIAGNOSIS. Species with long, slender, tubular body; head and foot hardly offset; trunk with seven longitudinal folds; apical corona with elongated, ventral buccal field; foot with two pseudosegments and acute, conical toes; rami with anterior projections; unci with six teeth, largest tooth ventrally with accessory toothlet; fulcrum rod-shaped, distally broadening; manubria club-shaped, slightly curved distally; hypopharynx with paired plates ventrally, bearing two large teeth each.

DESCRIPTION. Habitus. (Figs. 1A, B, 2AD, 4A-C, 5A-C) Proales tillyensis sp.n. has a hyaline, tubular and flexible body. Head and foot are not distinctly broader or narrower than the trunk. The whole body is divided into three distinct regions: head with neck, trunk and foot with toes (Fig. 1A, B). The epidermis is sparsely stiffened and has an almost smooth surface. The head is completely contractible into the trunk and divided into two pseudosegments, separat- ed from each other and the trunk by transverse folds (Figs. 1A, B, 4A, B, 5A). The anterior pseudosegment carries a small, rounded rostrum. The rostrum is separated from the anterior pseudosegment via a transverse fold. Dorsally the pseudosegment has a dorsal antenna (Figs. $1 \mathrm{~B}, 4 \mathrm{~B}, 5 \mathrm{~A}, \mathrm{C}$ ) and is followed caudally by the shorter neck pseudosegment (nps) (Figs. 1A, B, 4A, 5A). The corona appears semicircular in dorsal view. Its long, locomotory cilia are located apically (Figs. 1B, 5C); the ventral buccal field consists of numerous short cilia and extends to the center of the neck pseudosegment (Figs. 4C, 5B). The cylindrical trunk is usually divided into three pseudosegments differing in size and separated from each other by distinct transverse folds (Figs. 1A, B, 4A, B, C, 5A). The anteriormost, longest and broadest trunk pseudosegment bears at its posterior third two antennae in dorsolateral position (Figs. 4A, 5A). This pseudosegment bears also seven longitudinal folds (one long dorsomedian fold and three long dorsolateral ones on each side) and two shorter lateral folds (one on each side) (Figs. $1 \mathrm{~A}, \mathrm{~B}, 4 \mathrm{~A}, \mathrm{~B}, 5 \mathrm{~A})$. The pseudosegment is followed by a very short lumbar pseudosegment (lps). The lumbarpseudosegment is subsequently followed by a preanal pseudosegment (pps) that slightly overlaps the foot (Figs. 1A, B, 4A, 5A). Depending on the degree of contraction of the animal, the trunk can have two additional transverse folds: One fold in the anterior region (see arrow Fig. 5A) and one in the posterior region of the largest trunk pseudosegment (see arrows Figs. 4C, 5A). The completely contractible, broad and only slightly tapering foot is divided into two short foot pseudosegments and two short, acute, conical toes (Figs. 1A, B, 2D, 4B, C). Viewed dorsally, the toes are usually spread (Figs. 2D, 5A). The two short and broad pedal glands stretch through the foot and nearly fill out both foot pseudosegments completely (Fig. 2C, D).

Digestive system. (Figs. 1A, B, 2A-C) The digestive tract consists of a mouth opening, a spherical mastax, a narrow oesophagus, a stomach and an intestine (Figs. 1A, B, 2A-C). The mouth opening is located ventrally in the center 

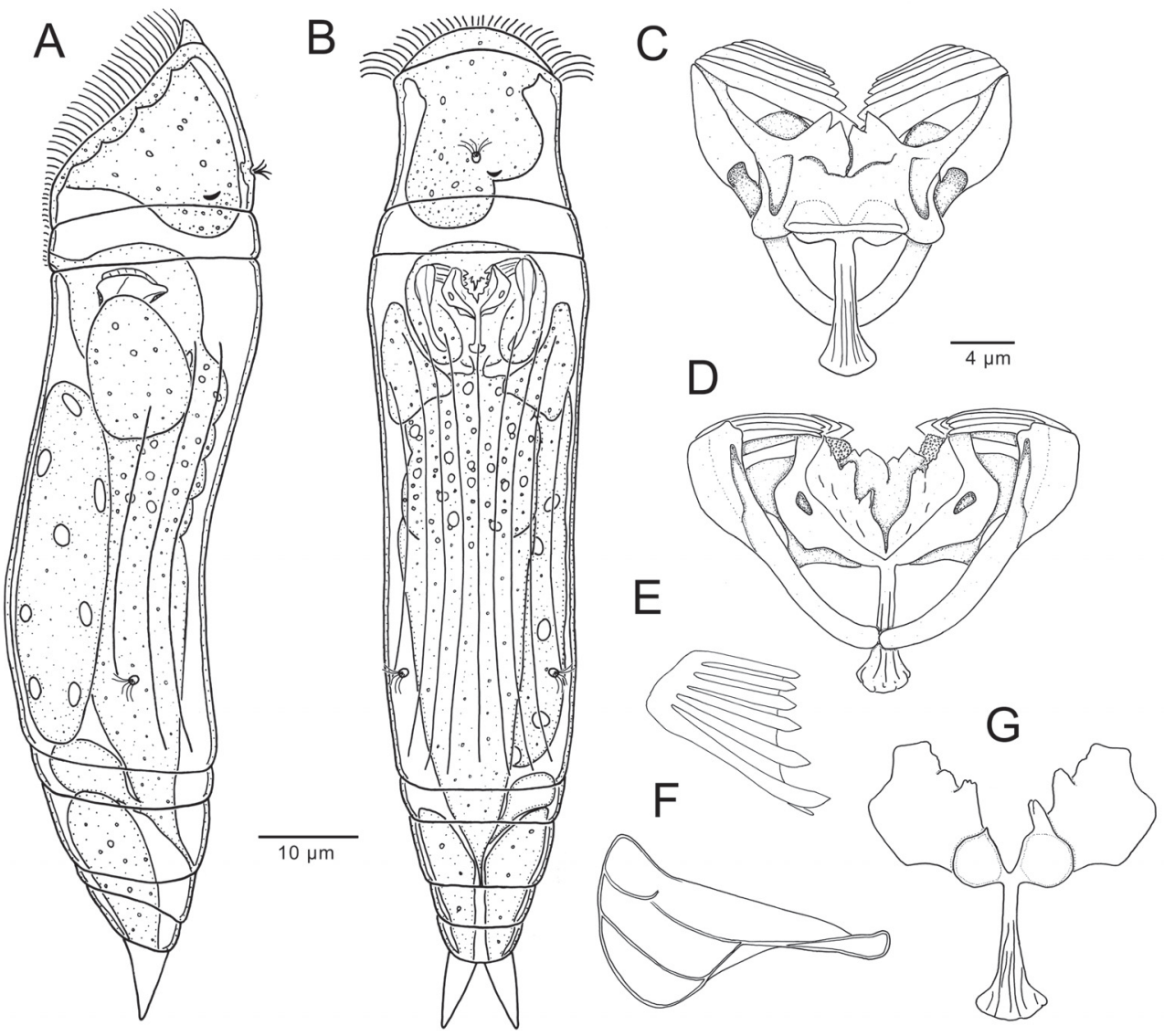

Fig. 1. General body organization of Proales tillyensis sp.n.

A - habitus in lateral view; B - habitus in dorsal view; C - trophi in ventral view; D - trophi in dorsal view; E uncus in frontal view; $\mathrm{F}$ - manubrium in lateral view; $\mathrm{G}$ - incus in ventral view.

Рис. 1. Общая организация Proales tillyensis sp.n.

А — вид сбоку; В — вид со спинной стороны; С - трофи с вентральной стороны; D - трофи с дорсальной стороны; Е - ункус с фронтальной стороны; F — манубриум сбоку; $\mathrm{G}$ - инкус с вентральной стороны.

of the neck pseudosegment and leads to a short buccal tube (Figs. 1A, 4C, 5B). The following mastax is located in the anterior trunk region (Fig. 2A, B). One pair of salivary glands is visible laterally in the mastax complex. The oesophagus diverges dorsally from the mastax and leads to the stomach that is filled with lipid droplets (Fig. 2A-C). From the anterior stomach wall one pair of bulbous, oval gastric glands (Fig. 2B). The stomach and the intestine are not separated by a prominent constriction (Fig. 2B). The intestine leads to the cloaca that opens dorsally below the preanal pseudosegment.
Mastax hard parts (trophi). (Figs. $1 \mathrm{C}-\mathrm{G}$, 2E, F, 3A-D, 5D, E, 6A-G) The trophi are bilaterally symmetrical and possibly represent an intermediate stage between malleate and virgate type. The fulcrum attaches obliquely to the rami and is oriented in the longitudinal axis of the body, with its prominent fan-shaped terminal end directing caudally. In ventral view it appears slender and rod-shaped and broadens terminally (Figs. 1C, D, 2E, F, 3B, 6A, D). Seen from lateral the fulcrum appears triangular with a high base, tapering ventrally more than dorsally to its terminal end (Fig. 6G). The rami appear truncate triangular in dorsal view (Fig. 1D, 6D). 

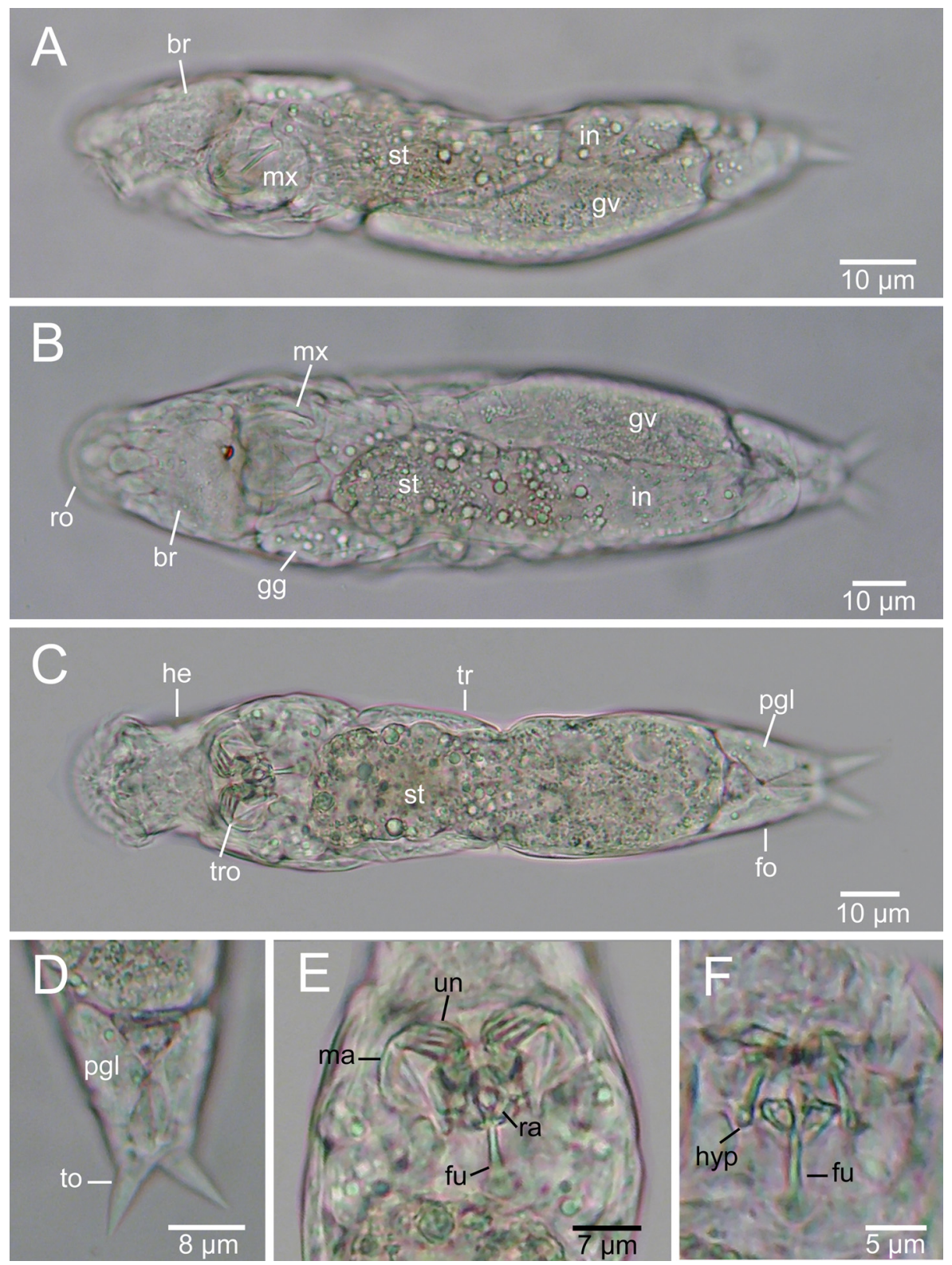

Fig. 2. Light microscopic images of Proales tillyensis sp.n.

A - specimen in lateral view; B - specimen in dorsal view; C - specimen in ventral view; D - foot; E - median section of mastax; F - ventral section of trophi; Abbreviations: br — brain, fo — foot, fu — fulcrum, gg — gastric gland, $\mathrm{gv}$ - germovitellarium, he — head, hyp - hypopharynx, in - intestine, ma - manubrium, $\mathrm{mx}$ - mastax, pgl - pedal gland, ra - ramus, ro - rostrum, st - stomach, to - toe, tr - trunk, tro - trophi, un - uncus.

Рис. 2. Организация Proales tillyensis sp.n. на тотальных препаратах в световой микроскоп.

А — вид сбоку; В - вид с дорсальной стороны; С — вид с вентральной стороны; D - нога; $\mathrm{E}$ - центральная часть мастакса; $\mathrm{F}$ - вентральная часть жевательного аппарата. Обозначения: $\mathrm{br}$ - мозг, fo - нога, fu фулькрум, gg - желудочная железа, gv — гонада, he — голова, hyp — гипофаринкс, in - кишечник, ma манубриум, mx - мастакс, pgl - педальная железа, ra - paмyc, ro - рострум, st - желудок, to - палец ноги, $\operatorname{tr}$ - туловище, tro — трофи, un - ункус. 

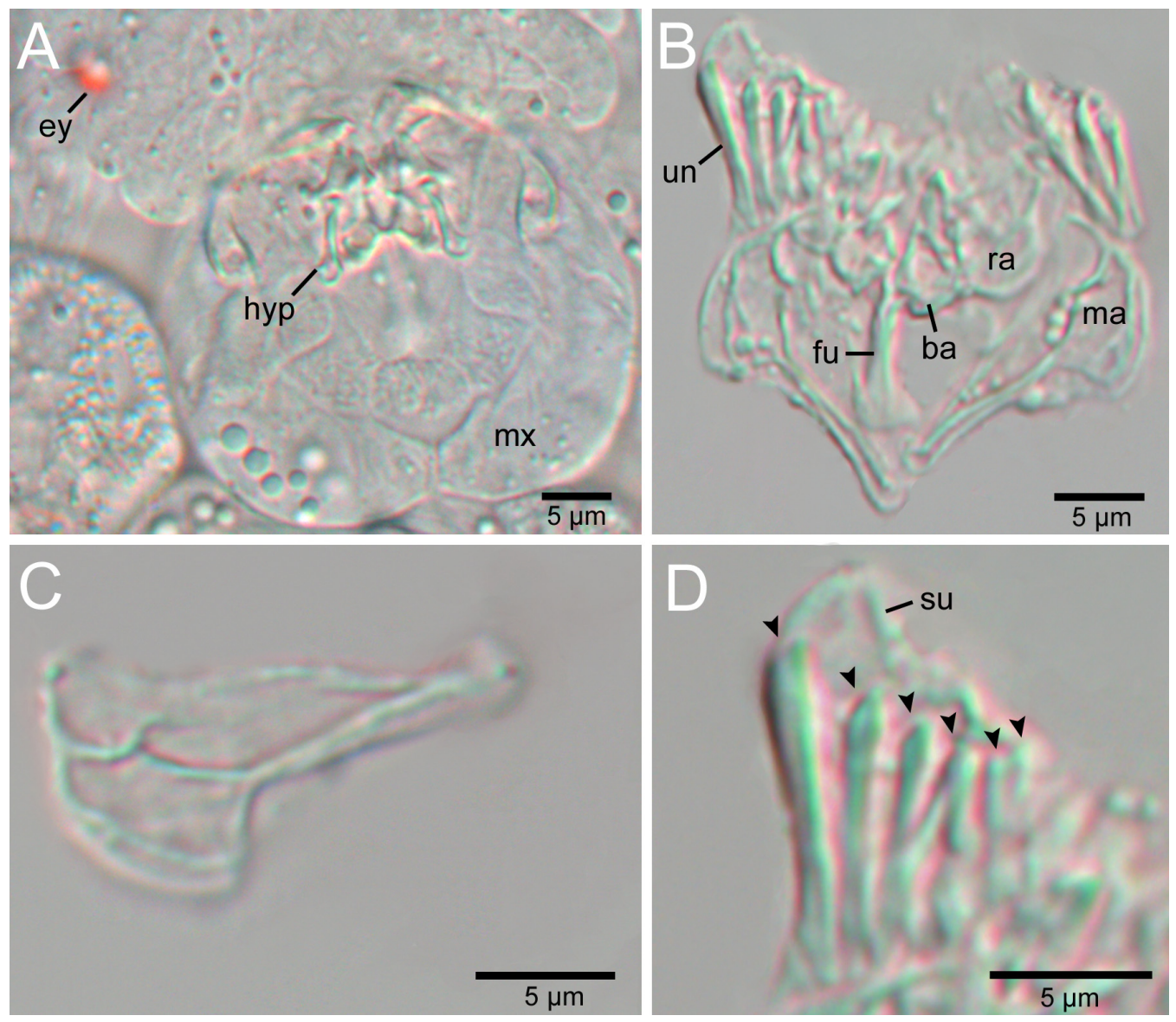

Fig. 3. Light microscopic details of the mastax of Proales tillyensis sp.n.

A - mastax in ventral view; B - dissolved trophi elements; C - manubrium; D - uncus (arrow heads indicate uncus teeth). Abbreviations: ba — basal apophysis, ey — eye, fu - fulcrum, hyp — hypopharynx, ma - manubrium, mx mastax, ra - ramus, su - subuncus, un - uncus.

Рис. 3. Детали строения масткса Proales tillyensis sp.n. по данным световой микроскопии.

А — мастакс, вид с вентральной стороны; В — изолированный жевательный аппарат (трофи); С — манубриум; $\mathrm{D}$ - ункус (наконечниками указаны зубы ункуса). Обозначения: ba - базальный апофиз, еу — глаз, fu фулькрум, hyp - гипофаринкс, ma - манубриум, mx - мастакс, ra - рамус, su - субункус, un - ункус.

Large, rounded apophyses are located on the ventral side of the rami, lateral to the proximal fulcrum end (Figs. 1G, 2F, 3B, 6A). The apophyses represent parts of the ramus subbasal chambers. The left apophysis has a thorn-shaped, terminally split projection (Figs. 1G, 5E, 6D), whereas the right apophysis has a hardly recognizable cusp (Figs. 1G, 3B). The inner margin of the left ramus subbasal chamber features one additional thorn-shaped projection as well as one tubercle-like swelling. The right ramus sub- basal chamber bears a three-toothed projection and two tubercle-like swellings (Figs. 3B, 5E, $6 \mathrm{D})$. The ramus basal chambers have straight lateral sides and curved anterior and posterior margins when seen in dorsal view (Figs. 1D, $6 \mathrm{D})$. Both the ramus basal and the ramus subbasal chamber display distinct openings with the small, circular ramus foramen subbasalis pointing caudally (Fig. 6B, E) and the small, oval centrally located ramus foramen basalis facing caudodorsally (Figs. 5E, 6D). A large, 


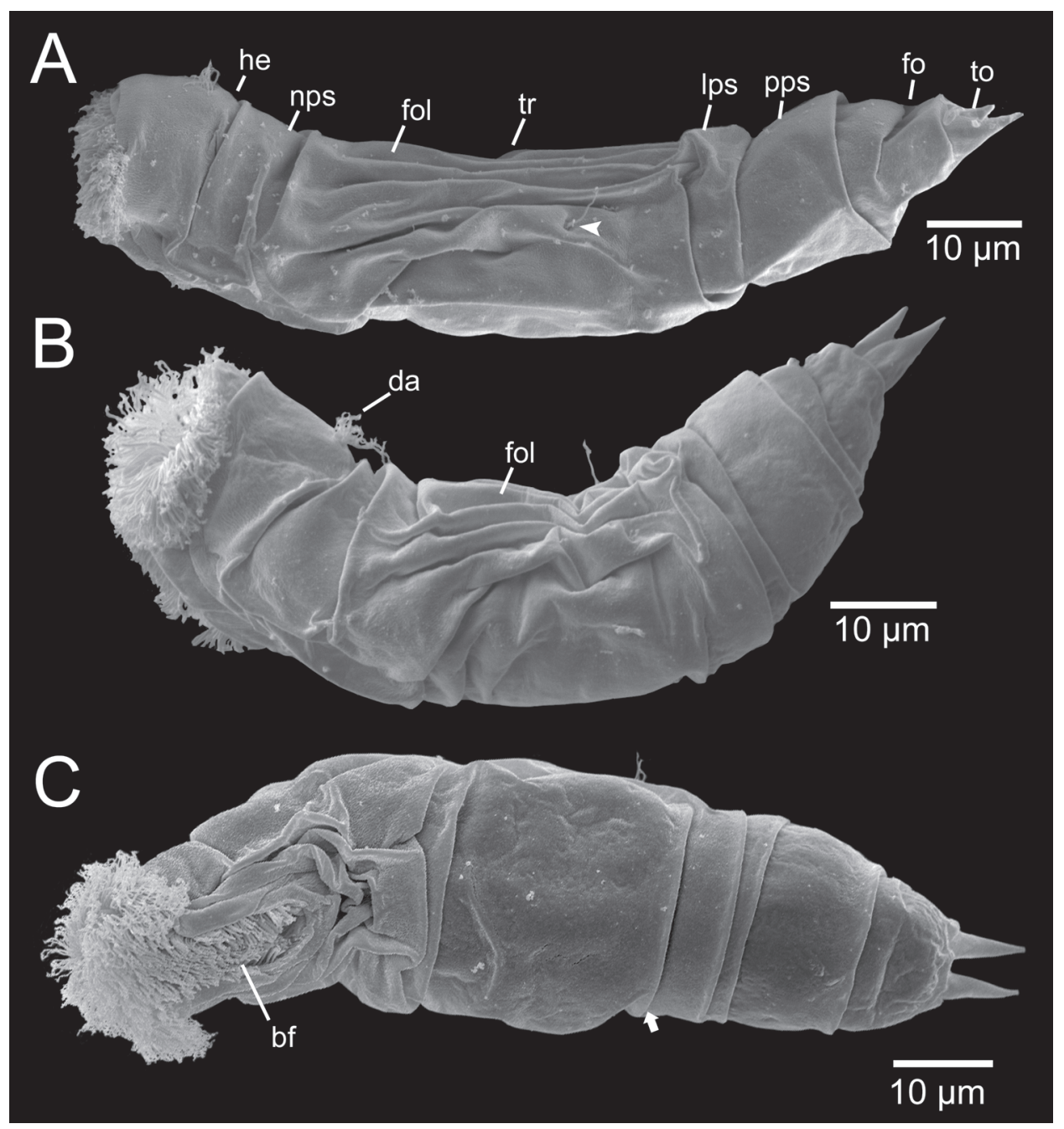

Fig. 4. Scanning electron microscopic (SEM) habitus images of Proales tillyensis sp.n.

$\mathrm{A}$-relaxed specimen in lateral view (arrowhead indicates position of lateral antenna); B — bent specimen in lateral view; $\mathrm{C}$ - specimen in ventral view (arrow indicates additional trunk fold). Abbreviations: bf — buccal field, da dorsal antenna, fo - foot, fol - longitudinal folds, he - head, lps - lumbar pseudosegment, nps - neck pseudosegment, pps — preanal pseudosegment, to - toe, tr - trunk.

Рис. 4. Внешний вид Proales tillyensis sp.n. по данным сканирующей электронной микроскопии (СЭМ).

А - расслабленный экземпляр сбоку (стрелкой указано положение латеральной антенны); В - изогнутый экземпляр сбоку; C - изогнутый экземпляр с вентральной стороны. Обозначения: bf — буккальное поле, da дорсальная антенна, fo - нога, fol - продольная складка, he - голова, lps - поясничный псевдосегмент, nps шейный псевдосегмент, pps — преанальный псевдосегмент, to — палец ноги, $\operatorname{tr}$ — туловище.

unpaired hypopharynx is located ventral to the rami. Anteriorly, it carries two strong, 2-toothed projections (Figs. 3A, 5E, 6A, D) and its caudolateral sides show somewhat more strongly cuticularized pockets (Figs. 2F, 3A, 6A). The paired unci are built on domed plates, each carrying six unci teeth decreasing gradually in size from the dorsalmost to the ventralmost 

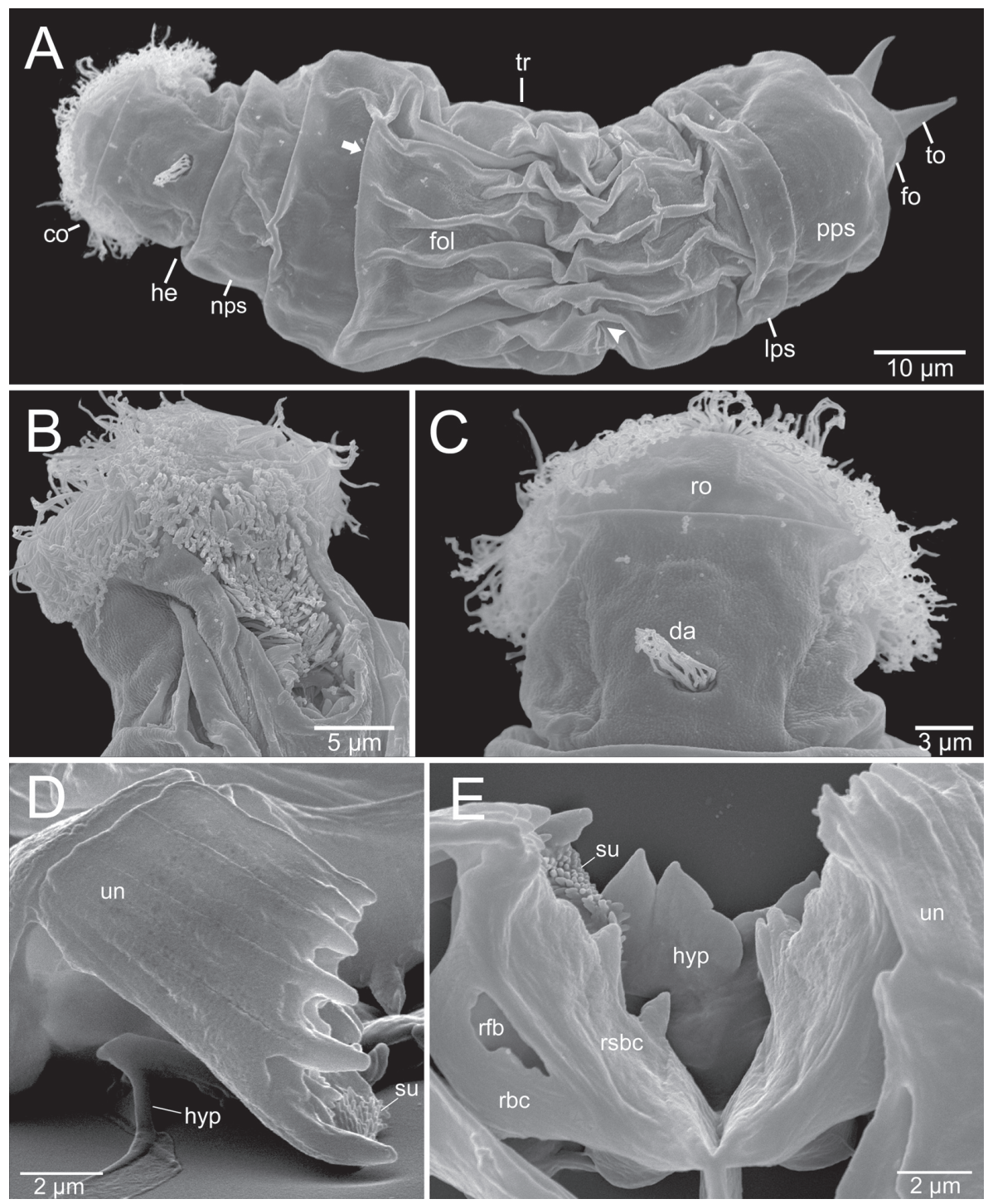

Fig. 5. Scanning electron microscopic (SEM) images of Proales tillyensis sp.n. with details of habitus and trophi.

A - relaxed specimen in dorsal view (arrow indicates additional trunk folds; arrowhead indicates position of lateral antenna); B - corona in ventral view with buccal field and mouth opening; $\mathrm{C}$ - head in dorsal view; D - uncus in frontal view; E — rami in dorsal view. Abbreviations: co — corona, da — dorsal antenna, fo - foot, fol — longitudinal folds, he - head, hyp - hypopharynx, lps - lumbar pseudosegment, nps — neck pseudosegment, pps — preanal pseudosegment, rbc - ramus basal chamber, rfb - ramus foramen basalis, rsbc — ramus subbasal chamber, ro rostrum, su - subuncus; to - toe, tr - trunk, un - uncus.

Рис. 5. Детали внешней морфологии и организации трофи Proales tillyensis sp.n.

A - раслабленный экземпляр с дорсальной стороны (стрелкой указаны дополнительные туловищные складки, наконечником указано положение латеральной антенны); В — вентральный вид на корону с буккальным полем и ротовым отверстием; С - голова с дорсальной стороны; D - ункус, фронтальный вид; $\mathrm{E}$ - рами, вид с дорсальной стороны. Обозначения: со — корона, da - дорсальная антенна, fo - нога, fol — продольные складки, he - голова, hyp - гипофаринкс, lps - поясничный псевдосегмент, nps - шейный псевдосегмент, pps преанальный псевдосегмент, rbc - базальная камера рамуса, $\mathrm{rfb}$ - базальное отверстие рамуса, rsbc суббуккальная камера рамуса, ro — рострум, su — субункус; to — палец ноги, $\operatorname{tr}$ — туловище, un — ункус. 


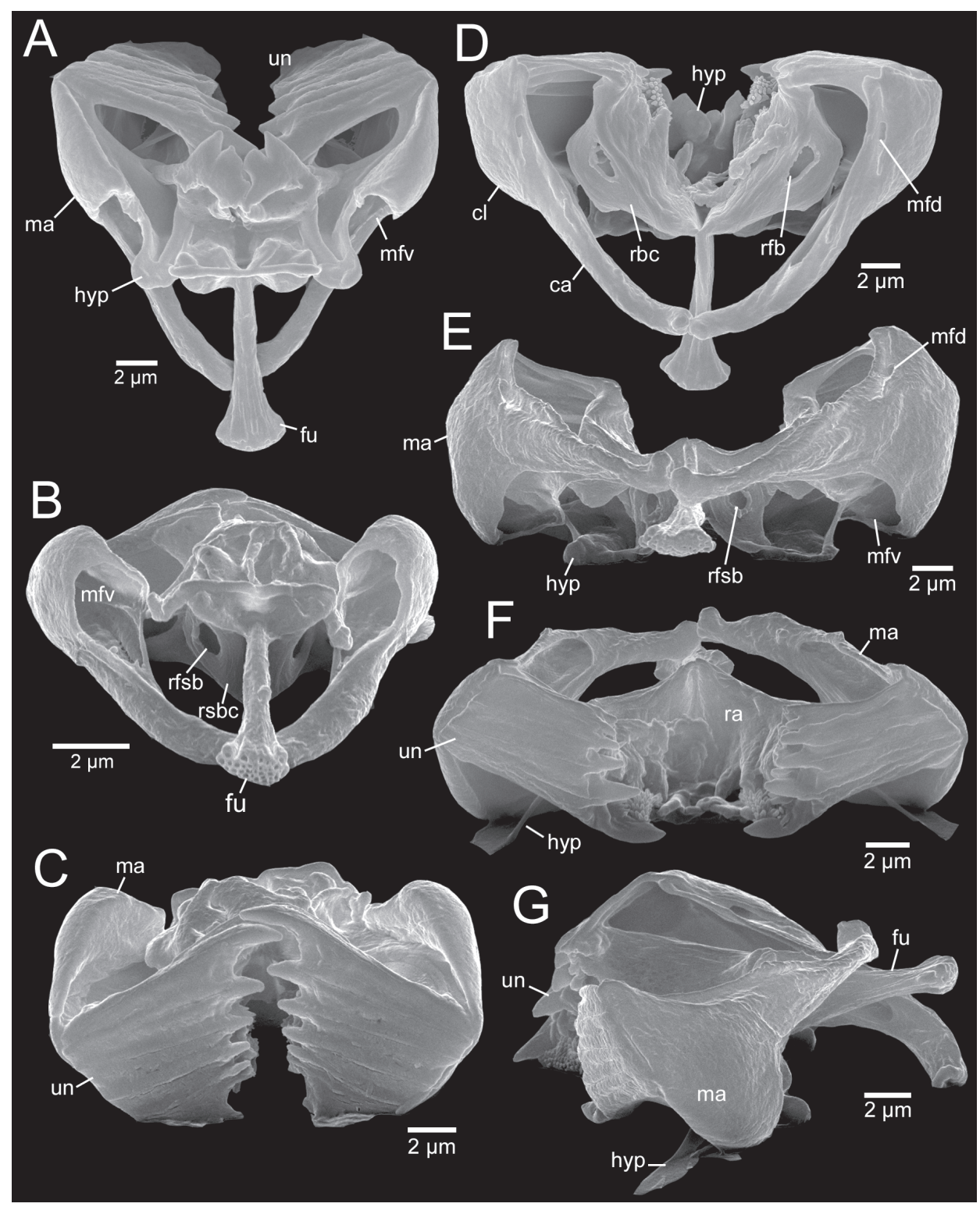

Fig. 6. SEM images of the mastax hard parts (trophi).

$\mathrm{A}$ - trophi in ventral view; $\mathrm{B}$ - trophi in ventrocaudal view; $\mathrm{C}$ - closed trophi in frontal view; $\mathrm{D}$ - trophi in dorsal view; $\mathrm{E}$ - trophi in caudal view; F — open trophi in frontal view; $\mathrm{G}$ - trophi in lateral view. Abbreviations: ca — cauda, $\mathrm{cl}$ - clava, fu - fulcrum, hyp - hypopharynx, ma - manubrium, mfd - manubrium foramen dorsalis, mfv manubrium foramen ventralis, ra - ramus, rbc - ramus basal chamber, rfb - ramus foramen basalis, rfsb - ramus foramen subbasalis, rsbc — ramus subbasal chamber, un - uncus.

Рис. 6. Жесткие части матакса (трофи) по данным СЭМ.

А — трофи, вид с вентральной стороны; В — трофи, вид с вентрокаудальной стороны; С — трофи с фронтальной стороны; D - трофи с дорсальной стороны; Е - трофи с каудальной стороны; F — отверстие трофи, вид с фронтальной стороны; G - трофи, вид сбоку. Обозначения: са — кауда, cl - бугорок, fu — фулькрум, һур гипофаринкс, ma - манубриум, mfd - дорсальное отверсие манубриума, mfv — вентральное отверстие манубриума, $\mathrm{ra}$ - рамус, $\mathrm{rbc}$ - базальная камера рамуса, $\mathrm{rfb}$ - базальное отверстие рамуса, $\mathrm{rfsb}$ - суббазальное отверстие рамуса, rsbc - суббазальная камера рамуса, un - ункус. 
tooth (Figs. 1E, 2E, 3B-D, 5D, 6C, F). Beneath each of the bent principal teeth lies an additional, small accessory toothlet. Further, a subuncus with scleropilar structures is located beneath the uncus (Figs. 1D, 3D, 5E). The club-shaped manubria (Figs. 1F, 3C, 6G) attach to the unci proximally by fine ligaments and taper gradually from the very prominent clava towards the end of the slender, inwardly curving cauda. The dorsal manubrial chamber is small and has a caudally directed, rip-shaped manubrium foramen dorsalis (Fig. 6D, E). The large ventral manubrial chamber displays a rounded, ventrocaudally directed manubrium foramen ventralis (Fig. 6A, B, E). Whereas the median and to a certain degree the dorsal manubrial chamber form the cauda, the ventral manubrial chamber is shorter and accounts only for two-fifths of the manubrial length. A distinct manubrium foramen medius was not recognizable.

Nervous system and sensory organs. (Figs. 1A, B, 2A, B) The large, saccate brain is situated in the head and reaches caudally to the mastax (Figs. 1A, B, 2A, B). A single, red cerebral eye is located at the posterior end of the brain. The eye is displaced to the right and lies in front of the left oriented retrocerebral organ (Figs. 1B, 2B). The dorsal antenna is located centrally on the head and consists of several cilia (Fig. 5C). The lateral antennae are located in the last third of the largest trunk pseudosegment (Figs. 4A, 5A).

Excretory system. (Fig. 1A, B) The protonephridial system consists of several pairs of distinct terminal organs distributed laterally in the body cavity, along the longitudinal axis of the animal. The collecting tubules open into a contractile bladder that is positioned ventrocaudally in the trunk (Fig. 1A, B). The fluid of the bladder is emptied into the terminal part of the intestine (cloaca).

Reproductive organs. (Figs. 1A, B, 2A, B) Proales tillyensis sp.n. is an oviparous species. The parthenogenetic females have a syncytial germovitellarium situated ventrolaterally in the posterior part of the trunk. The vitellarium contains eight nuclei (Fig. 1A, B). Some of the observed amictic females bore one large, ovoid egg.
MEASUREMENTS. Total length 85-170 $\mu \mathrm{m}$, maximum dorsoventral dimension $21 \mu \mathrm{m}$, maximum width $26-30 \mu \mathrm{m}$, foot length 16-18 $\mu \mathrm{m}$, toe length $8-9 \mu \mathrm{m}$, trophi length $16-19 \mu \mathrm{m}$, trophi width $17-18 \mu \mathrm{m}$, ramus length $8-9 \mu \mathrm{m}$, manubria length $16-17 \mu \mathrm{m}$, cauda width $9-10$ $\mu \mathrm{m}$ and fulcrum length $8-8.5 \mu \mathrm{m}$.

DISTRIBUTION AND ECOLOGY. The species was only found among floating bunches of a grass-like water plant (supposably a Potamogeton species) during the summer months from the end of July to early September, when the solar irradiation is high enough to warm up the water. In these gras bunches a lot of detritus accumulates, on which the species possibly feed. In samples the species swim in an even and slow rotating manner through the water, propelled along by the beating of the coronal cilia.

\section{Somatic musculature}

LONGITUDINAL MUSCLES (Figs. 7AC, 8A-E). The somatic musculature in five specimens was visualized by confocal laser scanning microscopy. Four specimens were examined in dorsoventral and one specimen in lateral position. In total, the somatic muscular system of $P$. tillyensis sp.n. comprises four longitudinal muscle pairs (musculus longitudinalis I-IV). Musculus longitudinalis I, II and III run from the head to the base of the toes, whereas musculus longitudinalis IV only extends from the head to the anteriormost third of the trunk. The longitudinal muscles differ in number of their subunits with musculus longitudinalis IV consisting of one subunit, musculus longitudinalis I and III consisting of three and musculus longitudinalis II consisting two subunits. Musculus longitudinalis I ( $\mathrm{m}$. longitudinalis ventralis) is the ventralmost pair of longitudinal muscles and reaches from the anterior trunk region to the terminal foot pseudosegment (Figs. 7A-C, 8A, B). The paired musculus longitudinalis II ( $\mathrm{m}$. longitudinalis lateralis medius) (Figs. 7B, C, 8A-D) runs laterally from the head to the terminal foot pseudosegment. Each muscle has two strands that both consist of two subunits. The inner 


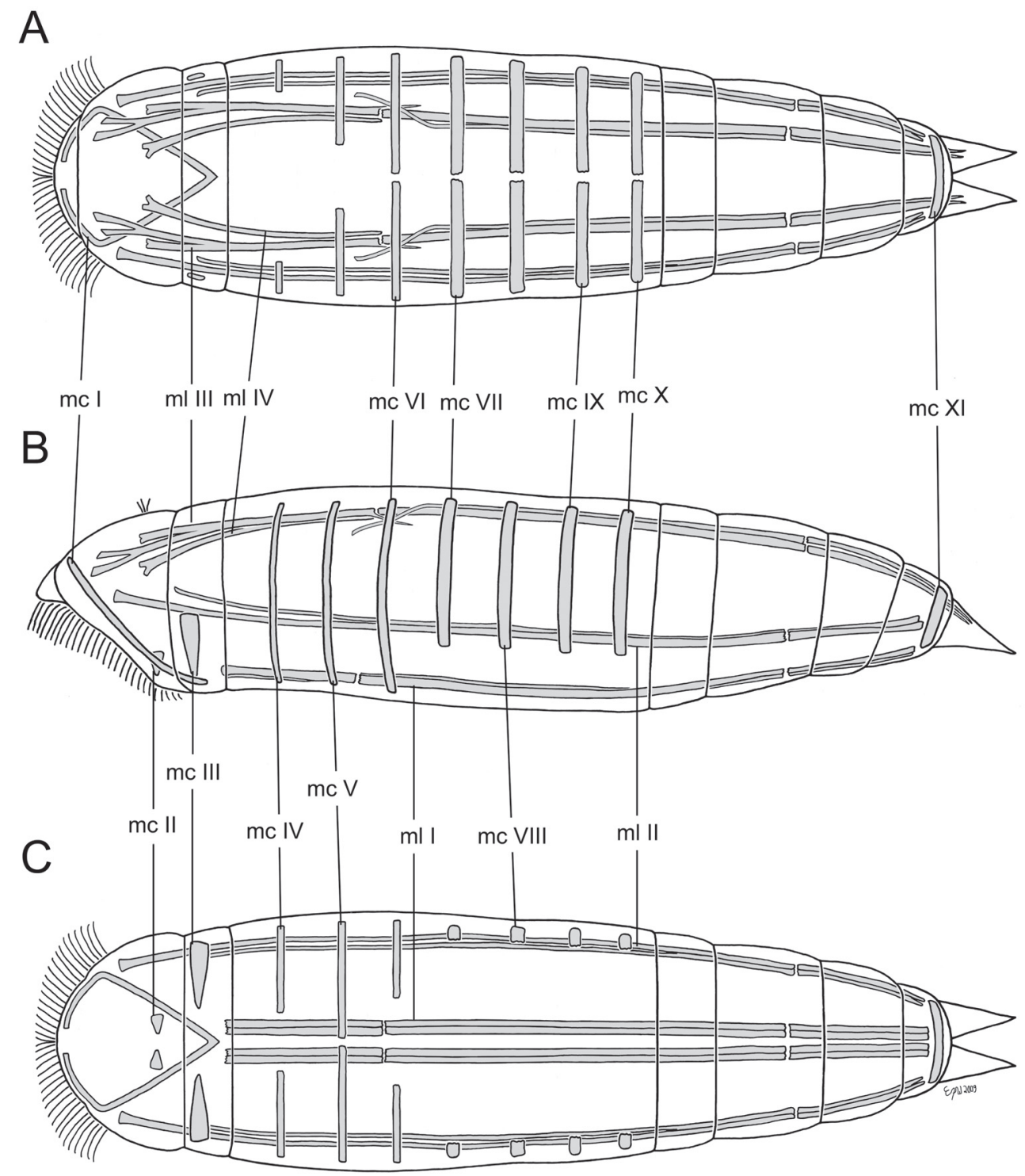

Fig. 7. Schematic drawing of the somatic musculature of Proales tillyensis sp.n.

A - dorsal view; B - lateral view; $\mathrm{C}$ - ventral view. Abbreviations: $\mathrm{mc}$ I-XI — musculus circularis I-XI, ml I-IV musculus longitudinalis I-IV.

Рис. 7. Схема организации соматической мускулатуры Proales tillyensis sp.n.

А - вид с дорсальной стороны; В - вид сбоку; С - вид с вентральной стороны. Обозначения: mc I-XI кольцевая мускулатура I-XI, ml I-IV — продольная мускулатура I-IV. 
strand of the muscle terminates in the neck pseudosegment, whereas the other strand anchors in the head. The broad musculus longitudinalis III ( $\mathrm{m}$. longitudinalis dorsalis) stretches along the dorsalmost part of the body, extending from the head to the toes. Its two strands anchor in front of the toe bases (Figs. 7A, B, 8A, B) and run frontally. On level of the mastax the slender, inner muscle strand crosses the broader, outer muscle strand and terminates (Fig. 7A, B). The broader muscle strand reaches to the head, where it splits into three separate terminals (Figs. 7A, $8 \mathrm{~A}$ ). The paired musculus longitudinalis IV ( $\mathrm{m}$. longitudinalis capitis) anchors dorsally bifurcate in the head and terminates in the anteriormost third of the trunk. Its caudal end seems to attach to the musculus longitudinalis III.

CIRCULAR MUSCLES (Figs. 7 A-C, 8AE). A total of eleven circular muscles (musculi circulares I-XI) were identified. Except for musculus XI, all circular muscles are interrupted dorsally or ventrally and show various degrees of incompleteness (Fig. 7A-C). The frontalmost circular muscle musculus circularis I (pars coronalis) is an almost complete ring in the frontal section of the head. In its course it follows the corona with its buccal field from ventral to dorsal (Figs. 7A, B, C, 8A, C, D) and displays in all investigated specimens a small dorsal interruption. The caudally following musculus circularis II is highly incomplete, trigonal-shaped and positioned ventrolaterally in the head at both sides of the buccal field (Figs. 7B, C, 8 A-C). The broad, trigonal-shaped musculus circularis III is located in the neck and runs from lateral to ventral (Figs. 7B, C, 8C, D). The median trunk region displays seven circular muscles (musculus circularis IV-X) arranged in eaqual distance to each other. Musculus circularis IV is a fine muscle that is located directly behind the neck (Figs. 7B, C, 8A). Its dorsal ends are widely separated (Fig. 7A), its ventral ends lie much closer together and almost reach to the musculus longitudinalis ventralis (Fig. 7C). The musculus circularis $\mathrm{V}$ is located on level of the mastax region and displays a broad dorsal separation (Fig. 7A), whereas the ventral ends come close together, virtually reaching the midline of the body (7C). The musculus circularis VI lies directly behind the mastax, is dorsally almost closed (Fig. 7A) but has ventrally a broad interruption (Fig. 7C). Musculus circularis VI is followed caudally by the musculi circulares VII-X. All these circular muscles are robust, dorsally almost closed and terminate in the ventrolateral trunk region (Figs. 7A-C, 8A). The musculus circularis XI (m. circumpedalis) presents the caudalmost circular muscle and forms a complete ring situated in front of the toe bases (Figs. 7A-C, 8B, E).

VISCERAL MUSCULATURE. Proales tillyensis sp.n. presents a complex network of visceral musculature characterized by delicate circular, longitudinal and transverse fibers associated with the corona, stomach, gut and cloaca (Fig. 8A, E). Especially the strong, crossstriated mastax musculature displays an intense fluorescence signal. These muscles are clearly visible in all analyzed specimens but are not described here in detail and are not considered in the reconstructions.

\section{Discussion}

Differential diagnosis. Concerning the habitus solely P. tillyensis sp.n. resembles Proales decipiens, Proales fallaciosa, Proales phaeopis Myers, 1933, Proales parasita (Ehrenberg, 1838) and Proales palimmeka Myers, 1940. Regarding the overall morphology, including the trophi, $P$. tillyensis sp.n. closely resembles $P$. fallaciosa and $P$. decipiens. Hence in the following, we mainly compare these three species (results are summarized in Tab.1). In order to do this we rely on our own observations and the descriptions given by Ehrenberg (1832), Wulfert (1937, 1939), Voigt (1957), Koste (1978) and De Smet (1996).

Proales tillyensis sp.n. is a small species with a maximum body length of $170 \mu \mathrm{m}$. Most of the examined specimens had a length of about $100-120 \mu \mathrm{m}$, therewith the species is definetly smaller as $P$. decipiens (120-270 $\mu \mathrm{m}$ body length) and much smaller than $P$. fallaciosa (200-320 $\mu \mathrm{m}$ body length). The body outline of $P$. decipiens is described as fairly constant; the 

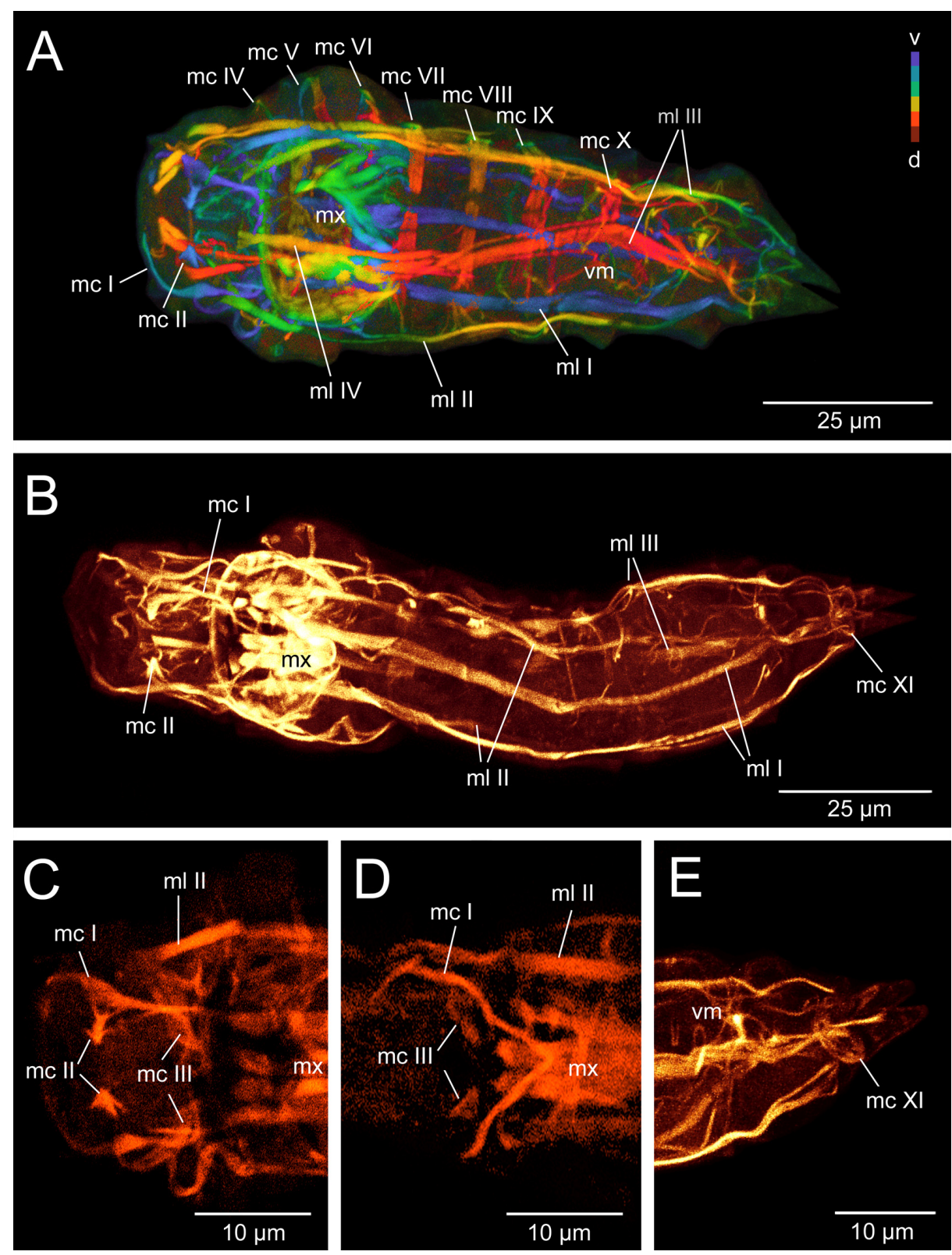

Fig. 8. Fluorescent staining of F-actin filaments in the musculature of Proales tillyensis sp.n., confocal laser scanning microscopy (CLSM).

A - depth-coded maximum projection (specimen 1); B — maximum projection (specimen2); $\mathrm{C}$ - median head region; $\mathrm{D}$ - ventral head region (notice caudally closed $\mathrm{mc}$ I); E - foot region. Abbreviations: $\mathrm{mc} \mathrm{I}$-XI - musculus circularis I-XI, $\mathrm{ml}$ I-IV - musculus longitudinalis I-IV, $\mathrm{mx}$ - mastax, vm — visceral musculature.

Рис. 8. Флюорисцентное окрашивание F-актиновых филаментов в мускулатуре Proales tillyensis sp.n., конфокальная лазерная сканирующая микроскопия (КЛСМ).

A - 3-D проекция с максимальной глубиной резкости (экземпляр 1); В - максимальная проекция (экземпляр 2); C — медианная часть головы; D — вентральная часть головы (каудально приближены mc I); E - область ноги. Обозначения: mc I-XI - кольцевые мышцы I-XI, ml I-IV - продольные мышцы I-IV, mx - мастакс, vm висцеральная мускулатура. 
Table1. Comparison of morphological and ecological characters of Proales fallaciosa, Proales decipiens and Proales tillyensis sp.n.

Таблица 1. Сравнительные морфологические и экологические характеристики Proales fallaciosa, Proales decipiens и Proales tillyensis sp.n.

\begin{tabular}{|c|c|c|c|}
\hline & Proales fallaciosa & Proales decipiens & Proales tillyensis sp.n. \\
\hline body length & $200-320 \mu \mathrm{m}$ & $120-270 \mu \mathrm{m}$ & $85-170 \mu \mathrm{m}$ \\
\hline $\begin{array}{l}\text { projection between } \\
\text { toes }\end{array}$ & present & absent & absent \\
\hline retrocerebral organ & displaced to left & displaced to left & displaced to right \\
\hline $\begin{array}{l}\text { stomach-intestine } \\
\text { constriction }\end{array}$ & absent & present & absent \\
\hline inflated toe bases & absent & occasionally present & absent \\
\hline $\begin{array}{l}\text { number of uncus } \\
\text { teeth }\end{array}$ & $\begin{array}{l}\text { 5-7 left / 4-6 right } \\
\text { (accessory toothlet } \\
\text { included) }\end{array}$ & $\begin{array}{c}4 \text { left } / 5 \text { right } \\
\text { (accessory toothlet } \\
\text { included) }\end{array}$ & $\begin{array}{c}6 \text { left } / 6 \text { right } \\
\text { (without accessory toothlet) }\end{array}$ \\
\hline $\begin{array}{l}\text { mid-ventral crest } \\
\text { on fulcrum }\end{array}$ & present & absent & absent \\
\hline habitat & $\begin{array}{l}\text { ponds, pools, waste } \\
\text { water }\end{array}$ & $\begin{array}{c}\text { ponds, pools, waste water, } \\
\text { Sphagnum }\end{array}$ & $\begin{array}{c}\text { in floating, grass-like plant } \\
\text { material of Lake Tilly }\end{array}$ \\
\hline diet & $\begin{array}{l}\text { algae, bacteria, dead } \\
\text { arthropods }\end{array}$ & $\begin{array}{c}\text { algae, bacteria, } \\
\text { ectoparasitic on } \\
\text { Stephanoceros }\end{array}$ & algae, bacteria, detritus \\
\hline $\begin{array}{l}\text { seasonal } \\
\text { appearance }\end{array}$ & perennial & autumn & summer \\
\hline pars coronalis & uninterrupted & - & dorsally interrupted \\
\hline $\begin{array}{l}\text { number of circular } \\
\text { muscles }\end{array}$ & 5 & - & 11 \\
\hline $\begin{array}{l}\text { musculus } \\
\text { circumpedalis }\end{array}$ & absent & - & present \\
\hline
\end{tabular}

same does not hold true for $P$. fallaciosa and $P$. tillyensis sp. n., whose body outline is variable. Like $P$. decipiens, the new species lacks the knob-like projection between the toes that is always present in $P$. fallaciosa. The retrocerebral organ in $P$. fallaciosa, and usually in $P$. decipiens, is displaced to the right, whereas it is displaced to the left in P. tillyensis sp.n.. Furthermore, $P$. decipiens presents a more or less deep constriction between stomach and intestine, whereas such a constriction is not obvious in P. fallaciosa or P. tillyensis sp.n.. The pedal glands of $P$. tillyensis sp.n. are, like those of $P$. decipiens, somewhat larger than in $P$. fallaciosa. The toe bases in P. decipiens are occasionally inflated, whereas those in $P$. tillyensis sp.n. and $P$. fallaciosa never have this shape. The hard parts of the jaw apparatus in P. fallaciosa and $P$. decipiens are characterized as modified malleate by Voigt (1957) and desig- nated as virgate by De Smet (1996). Possibly the trophi of $P$. fallaciosa, $P$. decipiens and $P$. tillyensis sp.n. represent an intermediate of the modified malleate and virgate type. The cuticularized mastax hard parts of the three species are very similar, especially regarding the uncus (rami and fulcrum), but differ in minor aspects. Over the three years of observation, both unci constantly feature 6 distinct uncus teeth in all examined specimens of $P$. tillyensis sp.n. (the small, hardly developed accessory toothlet ventral to the principal tooth not included), whereas the right uncus of $P$. decipiens has 5 teeth and the left uncus has 4 teeth (accessory toothlet included) (see Table 37 Fig. 1d in Voigt 1957 and Fig. 29a-i in Wulfert 1960). In the initial description of $P$. fallaciosa the drawings of Wulfert (1937) show unambiguously 5 distinct teeth on each uncus (including the well developed bent, accessory tooth). In his later descrip- 
tion of P. fallaciosa, Wulfert (1939) states 6 teeth on the right and 7 teeth on the left uncus (including the accessory toothlet). By contrast, Donner (1955) observed in P. fallaciosa 4 and 5 uncus teeth (the acessory tooth included) (see Fig. 31c in Donner 1955) and negates the number of uncus teeth mentioned by Wulfert (1939). Koste (1978) and Koste and Shiel (1990) stated 7 teeth on the left and 5 to 6 teeth on the right uncus (the acessory tooth included). In his description De Smet (1996) generalizes these data and quotes 4 to 7 uncus teeth for $P$. fallaciosa. These different observations lead to three possible conclusions: a) either not all previous light microscopic observations were precise or $b$ ) the different recorded numbers of uncus teeth documents a broad variability of $P$. fallaciosa regarding the unci (whereof we are not convinced) or c) in the past authors described different species all identified as P. fallaciosa and the name represents a previously not recognized species complex. In our opinion the latter is the most likely explanation. However, none of the previously observed numbers of uncus teeth is conform with the number of teeth we found in $P$. tillyensis sp.n.

In the new species the longitudinal axis of the fulcrum and the unci form an angle of approximately $90^{\circ}$ (Fig. 6), whereas the drawings of $P$. fallaciosa and $P$. decipiens in Wulfert (1937, 1939), De Smet (1996) and Koste (1976) display an angle of about $160^{\circ}$. Most likely this is based on misinterpretations of the conditions and the angle in both species also amounts to approximately $90^{\circ}$. Unlike in P. fallaciosa, the mid-ventral crest quoted by De Smet (1996) could not be observed in $P$. tillyensis sp.n. The new species has an unpaired hypopharynx (Figs. 1C, 3A, 6A) that is also present in P. fallaciosa and $P$. decipiens, admittedly it was not recognized previously. In fact, the more cuticularized and denticulate lateral parts of the hypopharynx were previously characterized misleadingly as paired, hammer-shaped epipharyngeal elements. It was not noticed previously that these parts are embedded in less strongly cuticularized material since sodium hypochlorite, suggested by De Smet (1998) and applied in previous studies, is more aggressive on less strongly cuticularized trophi structures than SDS/DTT we use in this study for trophi preparation. However valuable the use of sodium hypochlorite is for displaying the single trophi elements and the different chambers wherupon manubria and rami consist of, it often fails to preserve important, less strongly cuticularized structures and reflecting the natural, relative position of the trophi elements. For the same reason, the presence of a hypopharynx in Bryceella was only recently noticed (see Wilts et al. 2009b); the same applies for several other taxa (e.g. Mytilina Wilts unpublished).

P. tillyensis sp.n. was solely found among floating gras bunches in the shallow water of Lake Tilly and could not be sampled in the water column. In contrast, $P$. fallaciosa and $P$. decipiens can be found in the water column of small herbaceous waters and in waste water. The latter species is also reported from wet Sphagnum. Unlike P. fallaciosa that occurs in spring, summer as well as in autumn and winter, the new species occurs only during warm temperatures and the population collapses each time in the late summer or early autumn, respectively, indicating that the species is not perennial. Proales tylliensis sp.n. seems to feed on detritus, algae and bacteria like $P$. fallaciosa and $P$. decipiens, whereas the latter species is also ectoparasitic on Stephanoceros Ehrenberg, 1832 adults and eggs following Stevens (1907). In contrast, P. fallaciosa is also necrophagic and can be observed in dead crustaceans and dead insect larvae.

Somatic musculature within $\boldsymbol{P}$. tillyensis sp.n. and across Proales. The somatic muscle system in $P$. tillyensis sp.n. comprises bilaterally symmetrical longitudinal as well as complete and incomplete circular muscles. All muscles, including the musculature associated with the trophi, show a distinct cross-striation. In the following we compare the musculature of $P$. tillyensis sp.n. with the three hitherto studied species of Proales (see Sørensen, 2005). Furthermore, we enlarge the homology hypotheses suggested by Sørensen (2005).

With its musculature $P$. tillyensis sp.n. closely resembles $P$. fallaciosa. Both species have four 
longitudinal muscles spanning the entire body and one longitudinal muscle stretching from the head to a point in the anterior region of the trunk. Because of their course, position and function the four longitudinal muscles in these two species can reasonably be assumed to be homologous. The musculus longitudinalis I ( $\mathrm{m}$. longitudinalis ventralis) in P. tillyensis sp.n. and the corresponding muscle in $P$. fallaciosa (ventral trunk retractor, see Sørensen, 2005) run ventrally straight from the head to the foot. The musculus longitudinalis II ( $\mathrm{m}$. longitudinalis lateralis medius) in P. tillyensis sp.n. and its counterpart in $P$. fallaciosa (lateral trunk retractor, see Sorensen, 2005) stretch laterally from the caudalmost foot pseudosegment to the anterior region of the head. Like the dorsal trunk retractor in $P$. fallaciosa (see Sørensen, 2005) the musculus longitudinalis III (m. longitudinalis dorsalis) $P$. tillyensis sp.n. runs dorsally from the caudalmost foot pseudosegment to the head, where it trifurcates. The musculus longitudinalis IV (m. longitudinalis capitis) in P. tillyensis sp.n. and its equivalent in $P$. fallaciosa stretch from the anterior trunk region to the anterior head region. Both species also display a pars coronalis and further incomplete circular muscles in the trunk. Admittedly, the musculature in both species differs in some respects. The musculus longitudinalis lateralis medius in $P$. tillyensis sp.n. consists of two subunits (Fig. 7A), whereas the lateral retractor in $P$. fallaciosa consists of three subunits. On the contrary the musculus longitudinalis dorsalis in P. tillyensis sp.n. consists of three subunits (Fig. 7A) and the dorsal retractor in P. fallaciosa consists of two subunits. Furthermore, the caudal end of musculus longitudinal capitis in $P$. tillyensis sp.n. attaches to the musculus longitudinalis dorsalis and possibly represents a branch of the latter (Fig. 7A). Following Sørensen (2005) this is apparently not the case for $P$. fallaciosa. The pars coronalis in P. fallaciosa is complete, whereas it is dorsally interrupted in P. tillyensis sp.n. (Fig. 7A). Proales tillyensis sp.n. displays two highly incomplete circular muscles ventrally in the head, seven circular muscles in the trunk and one complete circular muscle in the foot (musculus circumpedalis) (Fig. 7A-C). By contrast, $P$. fallaciosa displays only four incomplete circular muscles in the trunk and lacks further circular muscles.

When comparing $P$. tillyensis sp.n. with $P$. fallaciosa, $P$. reinhardti and $P$. daphnicola homologous longitudinal muscles varying in some respects can also be found in the latter two species. Due to their position and function, the ventral trunk retractor in $P$. daphnicola and $P$. reinhardti can be considered homologous with the musculus longitudinalis ventralis in $P$. tillyensis sp.n. and the ventral trunk retractor in $P$. fallaciosa, respectively (see also Sørensen 2005). For the same reason the dorsal trunk retractor in $P$. daphnicola and $P$. reinhardti can be considered homologous with the musculus longitudinalis dorsalis in P. tillyensis sp.n. and the dorsal trunk retractor in $P$. fallaciosa, respectively. A lateral trunk retractor is lacking in $P$. reinhardti, whereas such a muscle is present in P. daphnicola, P. fallaciosa and P. tillyensis sp.n. (m. longitudinalis dorsalis). Although this muscle is much shorter in $P$. daphnicola, it can be considered to be homologous in all three species due to its orientation and function (see also Sørensen, 2005). It is conspicuous that $P$. daphnicola and $P$. reinhardti have further longitudinal muscles that $P$. fallaciosa and $P$. tillyensis n. sp. lack: lateral head retractor, ventrolateral retractor, foot extensor, ventral foot retractor and possibly dorsolateral retractor. Besides, $P$. reinhardti features a dorsal foot muscle, a toe abductor and a toe flexor and $P$. daphnicola has a lateral coronal retractor. Sørensen (2005) assumed that the presence of a foot retractor in $P$. daphnicola and $P$. reinhardti is correlated with the presence of an offset and movable foot. Following this argumentation, the presence of differentiated toe muscles is possibly correlated with the offset, spindleshaped and movable toes in $P$. reinhardti.

The circular muscles, unlike their longitudinal counterparts, are highly variable in size, orientation and completeness, making homology determination much more difficult. The four species of Proales so far investigated differ conspicuously in their number of circular mus- 
cles but all have a pars coronalis being interrupted dorsally only in P. fallaciosa. The pars coronalis can reasonably considered as homologous since it has evolved in the stem lineage of Ploima according to Riemann et al. (2008). A distinct coronal sphincter is only present in $P$. daphnicola and $P$. reinhardti. In the former species it is broad and almost complete but slender and only ventrally developed in the latter. Whilst in P. fallaciosa there is no trace of this huge mucle, the situation in P. tillyensis sp.n. is unclear. The species has a broad, trigonal, paired muscle ventral in the neck region (Fig. 7B, C). If this muscle possibly represents a reduced coronal sphincter is ambigous at the moment because in other so far investigated rotifer species (e.g. Epiphanes senta, Martini, 1912; P. reinhardti, P. daphnicola, Sørensen, 2005; Pleurotrocha petromyzon, Pleurotrocha robusta, Trichocerca sp. Wilts unpubl. data) the coronal sphincter is much more conspicuous, broader and completer than in this species. In a further comparison of the hitherto investigated species of Proales, it is noticeable that $P$. reinhardti has only three circular muscles, whereas $P$. fallaciosa has four, $P$. daphnicola five and $P$. tillyensis sp.n. seven circular muscles in the trunk (Fig. 7C). These muscles are only laterally developed in $P$. reinhardti, whereas they are almost closed dorsally in $P$. daphnicola and $P$. fallaciosa. In $P$. tillyensis sp.n. most of the circular trunk muscles are nearly closed dorsally and only the anteriormost ones have a broader dorsal interruption (Fig. 7A). A musculus circumpedalis is only present in P. tillyensis sp.n. (Figs. 7A-C, 8E). Based on the argument that the musculus circumpedalis is a ground pattern feature of Ploima (see Riemann et al., 2008; Riemann et al., 2009; Wilts et al., 2009) this muscle is homologous with the transverse toe muscle detected in $P$. reinhardti by Sorensen (2005) (see also Riemann et al., 2008).

Conclusion. Although P. tillyensis sp.n. can be diagnosed by several ecological and morphological characters regarding habitus, trophi and musculature the comparison with $P$. decipiens and $P$. fallaciosa was difficult due to their poor descriptions, that are not as informative as they should be. The repeated confusion of $P$. fallaciosa, $P$. sordida and $P$. decipiens as mentioned by Harring and Myers (1922), Voigt (1957) and Koste (1978) demonstrates this. Uncertain and varying characters shared by several species of Proales are listed in the species keys and descriptions. Especially the imprecise trophi descriptions possibly hide an unrecognized species complex. For the future a detailed analysis of $P$. fallaciosa, $P$. decipiens and further species of Proales, possibly with implementation of molecular methods, is preferable.

Within Proalidae, descriptions of the somatic musculature of three species of Proales (Sørensen, 2005) and one species of Bryceella (Wilts et al., 2009b) have been revealed previously. With this study detailed data on the musculature of five species of Proalidae is available. Unfortunately, these data are not sufficient enough to make conclusions on the ground plan of Proales regarding the body musculature because it is assumable that Proales doesn't represent a monophyletic taxon (Wilts et al., 2009a). In fact, the distinct agreement of the somatic musculature of P. tillyensis sp.n. and P. fallaciosa and the distinct differences with the somatic musculature of $P$. reinhardti suggest that there are two different muscular patterns in the genus ( $P$. daphnicola is excluded from this argumentation because we have recently found hints for a relationship with species of another Ploima genus, results are given in a following paper). The revealed data show that the two species groups within Proales (group A, resembling $P$. decipiens and group B resembling $P$. reinhardti) differ not only regarding their habitat, habitus and trophi morphology but also regarding their somatic musculature. A similar study focusing on the somatic musculature of another representative of group B (e.g. P. theodora or P. halophila) would be useful to support this hypothesis. A support would represent another factor arguing for a division of the genus.

\section{Acknowledgements}

We gratefully acknowledge the financial support of the Evangelisches Studienwerk Villigst e.V. granted to E.F. Wilts. A special thanks 
to Birger Neuhaus from the Museum für Naturkunde of the Humboldt-University, Berlin for deposition of the type material. Support was also provided by Deutsche Forschungsgemeinschaft DFG. Furthermore, we thank Prof. Dr. P. Martínez Arbizu from Senckenberg Research Institute, German Centre for Marine Biodiversity Research (DZMB), for providing the confocal laser scanning microscope. Valuable comments and criticism given by F. Leasi and an anonymous reviewer are also highly appreciated. Ms. Francesca Leasi contacted me and told me that she was one of the reviewers for the article and that she would be happy if I put her in the acknowledgements.

\section{References}

De Smet W.H. 1996. Rotifera 4: The Proalidae (Monogononta) // Dumont H.J., Nogrady T. (eds.). Guides to the Identification of the Microinvertebrates of the Continental Waters of the World. Amsterdam: SPB Academic Publishing BV. P.1-102.

De Smet W.H. 1998. Preparation of rotifer trophi for light and scanning electron microscopy // Hydrobiologia. Vol.387/388. P.117-121.

De Smet W.H. (in press.) Pourriotia carcharodonta, a rotifer parasitic on Vaucheria (Xanthophyceae) causing taxonomic problems // Bulletin de la Société Zoologique de France.

Donner J. 1955. Zur Rotatorienfauna Südmährens // Österreichische Zoologische Zeitschrift. Bd.5. S.30117.

Ehrenberg C.G. 1832. Über die Entwicklung und Lebensdauer der Infusionsthiere, nebst ferneren Beiträgen zu einer Vergleichung ihrer organischen Systeme // Abhandlungen der Akademie der Wissenschaften $\mathrm{zu}$ Berlin. S.1-154.

Harring H.K., Myers F.J. 1922. The rotifer fauna of Wisconsin // Transactions of the Wisconsin Academy of Science, Arts and Letters. Vol.20. P.553-662.

Kleinow W., Klusemann J., Wratil H. 1990. A gentle method for the preparation of hard parts (trophi) of the mastax of rotifers and scanning electron microscopiy of the trophi of Brachionus plicatilis (Rotifera) // Zoomorphology. Vol.109. No.6. P.329-336.

Koste W. 1978. Rotatoria. Die Radertiere Mitteleuropas. Ein Bestimmungswerk, begründet von Max Voigt. Ueberordnung Monogononta, 2nd ed. I. Textband. Berlin, Stuttgart: Gebrüder Borntraeger. 673 S.

Koste W., Shiel R.J. 1990. Rotifera from Australian inland waters. VI. Proalidae, Lindiidae (Rotifera: Monogononta) // Transaction of the Royal Society of South Australia. Vol.114. No.3. P.129-143.
Martini E. 1912. Studien über die Konstanz histologischer Elemente. III. Hydatina senta // Zeitschrift für wissenschaftliche Zoologie. Bd.102. S.425-645.

Melone G. 1998. The rotifer corona by SEM // Hydrobiologia. Vol.387-388. P.131-134.

Riemann O., Martínez Arbizu P., Kieneke A. 2008. Organisation of body musculature in Encentrum mucronatum Wulfert, 1936, Dicranophorus forcipatus (O. F. Müller, 1786) and in the ground pattern of Ploima (Rotifera: Monogononta) // Zoologischer Anzeiger. Vol.247. No.2. P.133-145.

Riemann O., Wilts E.F., Ahlrichs W.H., Kieneke A. 2009. Body musculature of Beauchampiella eudactylota (Gosse, 1886) (Rotifera: Euchlanidae) with additional new data on the trophi an overall morphology // Acta Zoologica. Vol.90. No.3. P.265-274.

Segers H.H. 1995. Rotifera 2: The Lecanidae (Monogononta) // H.J. Dumont, T. Nogrady (eds.). Guides to the Identification of the Microinvertebrates of the Continental Waters of the World. The Hague, The Netherlands: SPB Academic Publishing BV. P.1-226.

Segers H.H. 2007. Annotated checklist of the rotifers (Phylum Rotifera) with notes on nomenclature, taxonomy and distribution // Zootaxa. Vol.1564. P.1-104.

Sørensen M.V. 2005. Musculature in three species of Proales (Monogononta, Rotifera) stained with phalloidin-labelled fluorescent dye // Zoomorphology. Vol.124. P.47-55.

Stevens J. 1907. The Rotifera of the Exeter district // Proceedings of the College Field Club and Natural History Society, Exeter. Vol.1. P.30-52.

Voigt M. 1957. Rotatoria. Die Rädertiere Mitteleuropas. I. Textband. II. Taffelband. Berlin-Nikolassee: Gebrüder Borntraeger. P.1-508.

Wilts E.F., Bininda-Emonds O.R.P., Ahlrichs W.H. 2009a. Comparison of the predatory rotifers Pleurotrocha petromyzon (Ehrenberg, 1830) and Pleurotrocha sigmoidea Skorikov, 1896 (Rotifera: Monogononta: Notommatidae) based on light and electron microscopic observations // Zootaxa. Vol.2130. P.1-20.

Wilts E.F., Ahlrichs W.H., Martínez Arbizu P. 2009b. The somatic musculature of Bryceella stylata (Milne, 1886) (Rotifera: Proalidae) as revealed by confocal laser scanning microscopy with additional new data on its trophi and overall morphology // Zoologischer Anzeiger. Vol.248. No.3. P.161-175.

Wulfert K. 1937. Zur Kenntnis der Lebensgemeinschaften der Restlochgewässer des Braunkohlebergbaues I. Die Rädertiere // Zeitschrift für Naturwissenschaften. Bd.91. S.56-69.

Wulfert K. 1939. Beitrage zur Kenntnis der Radertierfauna Deutschlands IV. Die Rädertiere der Saale-Elster Niederung bei Merseburg in ökologisch-faunistischer Beziehung // Archiv für Hydrobiologie. Bd.35. S.663624.

Wulfert K. 1960. Die Rädertiere saurer Gewässer der Dübener Heide. I. Die Rotatorien des Zadlitzmoores und des Wildenhainer Bruchs // Archiv für Hydrobiologie. Bd.56. S.261-298.

Responsible editor E.N. Temereva 